Original Research

\title{
Heavy Metal-Induced Differential Responses to Oxidative Stress and Protection by Mycorrhization in Sunflowers Grown in Lab and Field Scales
}

\author{
Adinuţa Păun $^{1}$, Aurora Neagoe ${ }^{2 *}$, Mihaela Păun³ ${ }^{3}$ Ion Baciu', Virgil Iordache ${ }^{2}$ \\ 'Department of Organic Chemistry, Biochemistry and Catalysis, Faculty of Chemistry, \\ University of Bucharest, 90-92 Panduri Road, District 5, Bucharest, Romania \\ ${ }^{2}$ Research Centre for Ecological Services (CESEC), Faculty of Biology, \\ University of Bucharest, 91-95 Splaiul Independentei Street, District 5, Bucharest, Romania \\ ${ }^{3}$ Department of Statistics, University of Glasgow, G12 8QQ Glasgow, Scotland, UK
}

Received: 27 July 2014

Accepted: 16 November 2014

\begin{abstract}
The influence of arbuscular mycorrhizal (AM) fungi (Glomus intraradices) and of heavy metal stress on the characteristics of biomass production, as well as non-enzymatic and enzymatic variables in the roots, shoots, and leaves of sunflower (Helianthus annuus L.) plants were studied at pot and field scales. The intensity of the mycorrhizal colonization (M\%) and the arbuscular abundance in the root system (A\%) were found to be higher in the sunflower grown at lab scale (artificially inoculated) than that grown at field scale (natively inoculated). Thus, the AM symbiosis with the sunflower root system exposed to a different degree of pollution had a differential protective effect on plants at lab and field scales. A huge biomass of sunflower was harvested from the field compared to that obtained from the lab experiment. Furthermore, after measuring the biochemical variables of the plant parts, the results indicated a decrease in field for the superoxide dismutase and peroxidase activity, for the lipid peroxidation content, and for the assimilating pigments, while all quantified variables showed almost the same pattern of variation in all three plant parts. Consequently, it can be concluded that it is possible to use biochemical response variables, which in the case of our study are consistent with the protective effect of the fungus, as environmental biomarkers for soils with moderate pollution.
\end{abstract}

Keywords: oxidative stress variables, heavy metals, Helianthus annuus, arbuscular mycorrhizal fungi

\section{Introduction}

Heavy metals (HM) are some of the most frequent soil contaminants and a cause for long-term loss of soils, for destruction of natural habitats, loss of agricultural and inhabitable soils, and numerous health problems for wildlife and the human population. Reactive oxygen

*e-mail: auroradaniela.neagoe@g.unibuc.ro species (ROS) are generated during the normal metabolism of plants and activated by both biotic and abiotic stressors such as HM [1]. They are key messengers in plant responses to HM stress as part of their defense and adaptation mechanisms, either directly, by disturbing electron transport, or indirectly, by disturbing metabolic reactions, inactivation, and down-regulation of stress response enzymes and depletion of antioxidant substrates [2, 3]. They also affect the photosynthetic system at many levels, leading to 
symptoms such as defective photosynthetic structures (chloroplast membrane and thylakoid defects), loss of chlorophyll and carotenoid pigments, and inhibited photosynthetic activity of pigments [4-6]. The oxidative stress enzymes in plants, which are normally used to counteract the toxic byproducts of cell respiration, can also intervene to repair the damage done either directly by the action of $\mathrm{HM}$ or indirectly by the depletion of glutathione. Although normally expected to increase in activity with the accumulation of HM by plants, the activity of reactive oxygenscavenging enzymes is not so predictable. It is well known that the superoxide dismutase (SOD) usually acts as the first line of defense against ROS, preventing the accumulation of $\mathrm{O}_{2}^{-}$- radicals $[6,7]$. On the other hand, peroxidase (POD) is vulnerable to glutathione depletion from phytochelatin formation. In conclusion, all enzymes are vulnerable to loss of function as a result of interacting with HM [8].

Certain species of fungi have been known to accumulate metals such as $\mathrm{Hg}, \mathrm{Cd}, \mathrm{Se}, \mathrm{Cu}, \mathrm{Zn}$, and $\mathrm{Pb}$ at high levels, while other species are metal excluders $[9,10]$. Because most plants are mycorrhizal, the fungal hyphae often act as a buffer between the plant roots and the rhizosphere, increasing the area of absorption and also regulating plant intakes. The association between plants and rhizosphere microorganisms is ubiquitous and mutually beneficial. Contaminated substrates are often deficient in rhizosphere microorganisms due to low amounts of organic matter, poor plant growth, and extreme values of key variables. Supplementing rhizosferic areas with mycorrhizal inocula is of great importance for plant growth and the stabilization of metals into the substrate. Their beneficial effects have been tested in phytoremediation experiments and shown to improve plant growth and limit HM uptake [11-17]. The ecotoxicological effect of HM on plants is usually tested by measuring the concentration of pollutants in soil and/or in plants, and very rarely by measuring the response of plant biochemical variables [18]. Nevertheless, Dazy et al. [19] have published studies concerning the damage of some plant biochemical variables such as the enzymatic and non-enzymatic activities (SOD, POD, protein concentrations, and photosynthetic pigments) in leaves of plants grown on a strong HM pollution gradient. Other studies were carried out by Al Sayegh Petkovšek [20] on spruce needles and pointed out that, when the pollutant content decreased, the vitality of trees (assessed in terms of chlorophyll $a+b$ ) was improved. To our knowledge there is not enough information about the possible variation patterns of the biochemical variables of plants grown in different conditions of pollution, and even less in plant parts. If such patterns of variation were found, the oxidative stress variables could be used as environmental biomarkers.

In this context, the overall objective of this study was to present comparative results obtained from lab and field scales concerning the influence of AMF Glomus intraradices on selected oxidative stress variables caused by the presence of different contents of heavy metals, assessed in sunflower. To achieve this objective the following hypotheses were tested:
- Hypothesis 1. The biomass production will be positively influenced by the mycorrhizal fungi, but will distinguish a different pattern of variation as an effect of different scales and levels of pollution.

- Hypothesis 2. The biochemical variables of plants grown in soils with different degrees of pollution and the mycorrhizal fungi content at laboratory and field scales will register different values, but the variation patterns of the same plant parts will be similar.

\section{Material and Methods}

\section{Soil Sampling and Characterization}

The used soils were not dark in color, presented a high quantity of clay, calcareous concretions, and a thin layer $(5$ to $8 \mathrm{~cm})$ of cemented organic matter on the surface, and correspond to the podzoluvisol soils according to FAO/UNESCO classification [21]. Sampling was performed from the aluminium industrial area of Slatina (ALRO) located in southern Romania, in the Muntenia region (geographical coordinates: $44^{\circ} 26^{\prime} 13^{\prime \prime} \mathrm{N}, 24^{\circ} 22^{\prime} 12^{\prime \prime} \mathrm{E}$ in WGS84 system).

The soil samples were sampled in two campaigns. The first one consisted of sampling from two different areas of four square meters each, at a depth of about $20 \mathrm{~cm}$, and located $200 \mathrm{~m}$ from the pollution source. Each of these soils was strongly homogenized by hand, thus obtaining two composite samples coded with $\mathrm{C}_{1}$ and $\mathrm{C}_{2}$. In addition, two other composite samples, coded with $\mathrm{C}_{1} \mathrm{I}$ and $\mathrm{C}_{2} \mathrm{I}$, were inoculated with Glomus intraradices. During this campaign we also obtained a sample of uncontaminated soil (coded with $U$ ) from an area located outside Slatina, using the same sampling method as in the case of contaminated soils. This soil sample was considered the positive control. In the second campaign, we sampled 10 soil samples from an area of about two hectares of farmland cultivated with sunflower (noted with $\mathrm{S}$ ), which was slightly contaminated in comparison with $\mathrm{C}_{1}$ and $\mathrm{C}_{2}$ and located in Slatina, but outside the industrial area (about $1.8 \mathrm{~km}$ away from the pollution source). The quantity of soils collected was of about $2 \mathrm{~kg}$ per sample, and they were manually homogenized after that.

Soils $\mathrm{C}_{1}$ and $\mathrm{C}_{2}$ were polymetallic polluted (As, $\mathrm{Cr}, \mathrm{Mn}$, and Ni), for more details see Păun et al. [22], S was slightly contaminated while $U$ presented an element content with values in the range of acceptable limit for plants, as can be seen in Table 1 [23-25]. The $\mathrm{pH}$ of soils $\mathrm{S}$ and $\mathrm{C}_{2}$ belonged to the acidic class $(<5.5)$, while soils $\mathrm{U}$ and $\mathrm{C}_{1}$ had a $\mathrm{pH}$ belonging to the neutral class $(\leq 7)$, according to the INRA classification [26]. Concerning the nitrogen $\left(\mathrm{N}-\mathrm{NH}_{4}^{+}, \mathrm{N}-\mathrm{NO}_{3}^{-}, \mathrm{N}_{-} \mathrm{NO}_{2}^{-}\right)$ content in soils $\mathrm{U}$ and $\mathrm{S}$, there was a sufficiency content $\left(\geq 50 \mathrm{mg} \cdot \mathrm{kg}^{-1}\right)$ for the development of many plants, according to Griffin [27], whereas in $\mathrm{C}_{1}$ and $\mathrm{C}_{2}$ a lack of mineral nitrogen was found. The available phosphorus $\left(\mathrm{P}_{-} \mathrm{PO}_{4}^{3-}\right)$ registered higher concentrations in soil $\mathrm{U}$, but all soil samples presented a lack of available phosphorus $\left(<60 \mathrm{mg} \cdot \mathrm{kg}^{-1}\right)$ according to Howard [28]. The bioavailable forms of nitro- 
Table 1. General physicochemical characteristics of investigated soils after plant harvesting.

\begin{tabular}{|c|c|c|c|c|c|c|}
\hline \multicolumn{2}{|c|}{ Variable } & $\mathrm{U}(\mathrm{n}=4)$ & $S(n=10)$ & $C_{1}(n=4)$ & $\mathrm{C}_{2}(\mathrm{n}=4)$ & Accepted range* \\
\hline \multicolumn{2}{|l|}{$\mathrm{pH}\left(\mathrm{H}_{2} \mathrm{O}\right)$} & $7.043 \pm 0.264$ & $5.50 \pm 0.26$ & $6.38 \pm 0.037$ & $5.30 \pm 0.022$ & \\
\hline \multicolumn{2}{|l|}{$\mathrm{EC}(\mu \mathrm{S} / \mathrm{cm})$} & $102.0 \pm 9.129$ & $42.8 \pm 7.05$ & $140.2 \pm 20.56$ & $85.00 \pm 7.528$ & \\
\hline \multicolumn{2}{|l|}{$\mathrm{H}(\%)$} & $12.00 \pm 0.941$ & $7.30 \pm 2.06$ & $13.80 \pm 0.443$ & $15.68 \pm 1.655$ & \\
\hline $\mathrm{N}-\mathrm{NH}_{4}^{+}$ & \multirow{9}{*}{$\mu \mathrm{g} \cdot \mathrm{g}^{-1}$ d.w. } & $49.67 \pm 2.479$ & $14.70 \pm 8.44$ & $34.39 \pm 6.140$ & $32.02 \pm 3.688$ & \\
\hline $\mathrm{N}^{-\mathrm{NO}_{3}^{-}}$ & & $0.720 \pm 0.209$ & $48.20 \pm 33.26$ & $1.271 \pm 0.856$ & $2.756 \pm 0.267$ & \\
\hline $\mathrm{N}-\mathrm{NO}_{2}^{-}$ & & $0.090 \pm 0.117$ & $0.50 \pm 0.16$ & $0.015 \pm 0.020$ & $0.037 \pm 0.061$ & \\
\hline $\mathrm{P}-\mathrm{PO}_{4}^{3-}$ & & $45.89 \pm 6.926$ & $18.30 \pm 1.63$ & $37.12 \pm 9.829$ & $28.41 \pm 6.442$ & \\
\hline As & & $11.78 \pm 0.296$ & $9.1 \pm 2.13$ & $12.73 \pm 2.461$ & $13.02 \pm 0.753$ & 2 \\
\hline $\mathrm{Cr}$ & & $17.97 \pm 2.95$ & $30.1 \pm 3.85$ & $101.5 \pm 13.64$ & $106.5 \pm 2.692$ & $50-100$ \\
\hline $\mathrm{Mn}$ & & $344.9 \pm 58.4$ & $748.1 \pm 202.8$ & $864.3 \pm 89.64$ & $717.2 \pm 137.5$ & $270-525$ \\
\hline $\mathrm{Ni}$ & & $22.71 \pm 3.549$ & $57.74 \pm 10.40$ & $57.84 \pm 8.484$ & $58.17 \pm 3.686$ & 35 \\
\hline $\mathrm{P}$ & & $708.8 \pm 11.42$ & $639.9 \pm 33.58$ & $544.5 \pm 37.70$ & $588.3 \pm 42.12$ & $50-1,000$ \\
\hline
\end{tabular}

$\mathrm{U}$ - uncontaminated soil, $\mathrm{C}_{1}$ - contaminated soil $1, \mathrm{C}_{2}$ - contaminated soil 2, S - field soil, $\mathrm{H}$ - humidity, EC - electrical conductivity, $\mathrm{n}$ - number of replicates.

*Accepted range in soil for plants used by human population, according to Kabata-Pendias and Pendias [25], Kirkman et al. [23], and Foth and Ellis [24]. Observation: part of these results, respectively for $\mathrm{U}, \mathrm{C}_{1}$, and $\mathrm{C}_{2}$, have already been published in Păun et al. [22]. They are reloaded here only for a better understanding of the comparison of the substrates.

gen and phosphorus were determined according to the methods described by Neagoe et al. [29]. The soil samples were subjected to pressure-assisted digestion (Anton Paar, Multiwave 3000) with aqua regia (suprapure acids from Merck, $\mathrm{HCl}: \mathrm{HNO}_{3}=3: 1 \mathrm{v} / \mathrm{v}$ ) [30] using a program in three steps with a progressive increase of IR up to $210^{\circ} \mathrm{C}$ and pressure up to $40 \mathrm{bar}(0.3 \mathrm{bar} / \mathrm{s})$ for $65 \mathrm{~min}$., without filtering the samples before measuring them. Every digestion batch had one blank and two analytical replicates. The quality assurance and quality control criteria were satisfied by checking the standard reference material CRM $142 \mathrm{R}$ for trace elements in a light sandy soil. The differences were of no more than $5 \%$. The analysis of the ions of solution elements was done using mass spectrometry with inductively coupled plasma ICP-MS, Perkin-Elmer ELAN DRC-e6000 , with axial field technology for trace and rare earth element analyses. Standard solutions were prepared by diluting a $10 \mu \mathrm{g} / \mathrm{ml}$ multielement solution (Multielement ICP Calibration Standard 3, matrix 5\% $\mathrm{HNO}_{3}$, Perkin Elmer Pure Plus).

\section{Experimental Design}

After sterilization by autoclaving $\left(2.2\right.$ bar, $130^{\circ} \mathrm{C} \times 30$ $\min \times 2$ times), soils $\mathrm{C}_{1}, \mathrm{C}_{2}$, and $\mathrm{U}$ were used in a pot experiment (a $400 \mathrm{ml}$ polyethylene pot), which was carried out for 45 days in a growth chamber with controlled conditions: $60 \%$ relative humidity and light/dark cycle regime of $16 \mathrm{~h}$ light $/ 22^{\circ} \mathrm{C}$ and $8 \mathrm{~h}$ dark $/ 16^{\circ} \mathrm{C}$, and a $5000 \mathrm{~lx}$ light intensity. The pots were arranged in a randomized pattern within the growth chamber and rearranged every two days to minimize the microclimate variation. For each soil, four replicates were prepared using soils $\mathrm{U}, \mathrm{C}_{1}$, and $\mathrm{C}_{2}$, plus $10 \%$ expanded clay, and soils $\mathrm{C}_{1} \mathrm{I}$ and $\mathrm{C}_{2} \mathrm{I}$ were inoculated with $10 \%$ of Glomus intraradices sequestered in expanded clay, leading to a total of 20 pots. These experimental treatments were part of a larger experiment with nine experimental treatments and four replicates each that had already been published in Păun et al. [22, 31]. Some of the measured variables are presented again in this article in order to understand the experimental design, and to be able to compare the lab scale with the field one. The inoculation was performed using a commercial product AMF 510 (160 spores per g soil), provided by the "Institute für Pflanzenschutz,' Hanover University, Germany [32]. The soils were sown with 5 sunflower seeds per each pot and were maintained at a maximum water holding capacity by daily watering with distilled water and weighing the pots. When plant biomass increased, water volume progressively increased from 10 to $20 \mathrm{ml}$ over the initial weight. All sown seeds germinated, thus the number of seeds was equal to the number of plant individuals grown in each pot. This plant species was selected taking into account the historical data, which showed that sunflower was cultivated on soils $\mathrm{C}_{1}$ and $\mathrm{C}_{2}$ years ago, before increasing the degree of contamination. This plant species is still present in the cultivated soil $\mathrm{S}$ with a relatively lower contamination. On the other hand, sunflower germinates and grows relatively quickly, and more than that, it shows great potential for mycorrhization. 


\section{Field Campaign}

From the slightly polluted area (S), besides the 10 soil samples we also sampled 10 individuals of sunflower grown on agricultural field (age 45 days). Each soil sample was sampled from the rhizosphere of every individual sunflower. After measuring the plant variables, the results were compared to those obtained from the lab experiment.

\section{Plant Sampling and Processing}

After being harvested, the plants were weighed and portioned for analyses into roots, shoots, and leaves. The roots of the plants were briefly washed with tap and finally with distilled water. Then, a part of them was preserved in a solution obtained from $45.85 \%$ ultrapure water, $45.85 \%(\mathrm{v} / \mathrm{v})$ ethanol, $6 \%(\mathrm{v} / \mathrm{v})$ formaldehyde, and $2.3 \%(\mathrm{v} / \mathrm{v})$ acetic acid. Histochemical staining was then performed to the roots, thus preserved in order to highlight the AMF according to the method described by Schmitz et al. [33]. The preserved roots were washed, transferred into $2 \% \mathrm{KOH}(\mathrm{w} / \mathrm{v})$, and heated at $95^{\circ} \mathrm{C}$ for $15 \times 2 \mathrm{~min}$. They were then acidified for $15 \mathrm{~min}$ with $3.7 \% \mathrm{HCl}(\mathrm{v} / \mathrm{v})$. Subsequent staining was done using a $50 \%$ solution of blue lactophenol. The estimation of the degree of mycorrhyzation was performed according to Trouvelot et al. [34]. From each experimental treatment at lab scale, we used a total of 112 subsamples ( 4 replicates $\times 4$ roots from each $\times 7$ root fragments), and at field scale, a total of 280 subsamples ( 10 replicates $\times 4$ roots from each $\times 7$ root fragments) were used. Each of the 7 fragments from all lab and field plants, with lengths of $1 \mathrm{~cm}$, was rinsed with distilled water and then placed on slides with $100 \%$ glycerol. The root fragments were visualized by Carl Zeiss Axio Imager 2 microscopy (Jena, Germany) at $\times 40$ magnification.

After counting the vesicles, the arbuscules, and the hyphae, the intensity of mycorrhizal colonization ( $\mathrm{M} \%)$ and the abundance of arbuscules in the root system (A\%) were calculated. Then all plant material was frozen and lyophilized in order to determine the dry weight (d.w.), ground in a stainless steel mill and stored at $-20^{\circ} \mathrm{C}$ until processing. Element analysis was performed using the same ICP-MS instrument as described in Soil Sampling and Characterization section, after digestion with suprapure Merck 65\% nitric acid and using a three-step program with progressive increase of IR up to $140^{\circ} \mathrm{C}$ and pressure up to $40 \mathrm{bar}(0.3 \mathrm{bar} / \mathrm{s})$ for $45 \mathrm{~min}$. Every digestion batch had one blank and two analytical replicates. The quality assurance and quality control criteria were satisfied by checking the standard reference material CRM 281 of ryegrass. The differences were no more than $5 \%$.

\section{Protein Extraction and Determination of Antioxidant Enzymes}

Samples of $100 \mathrm{mg}$ plant material (roots, shoots, and leaves) were homogenized in $4 \mathrm{ml}$ of cold $100 \mathrm{mM}$ $\mathrm{K}_{2} \mathrm{HPO}_{4} / \mathrm{KH}_{2} \mathrm{PO}_{4} \quad(\mathrm{pH} \quad 7.2)$ buffer containing $2 \%$ polyvinylpyrrolidone, $2 \mathrm{mM}$ chelaplex III (EDTA), and
$2 \mathrm{mM}$ dithioerythritol (DTT). After centrifuging the samples for 20 minutes at $6000 \mathrm{rpm}$ and $4^{\circ} \mathrm{C}$, the obtained supernatant was dialyzed against a $5 \mathrm{mM} \mathrm{K}_{2} \mathrm{HPO}_{4} / \mathrm{KH}_{2} \mathrm{PO}_{4}$ (pH 7.2) buffer at $4^{\circ} \mathrm{C}$ for 8 hours and used to determine protein concentration, superoxide dismutase, and peroxidase. The protein concentration was determined according to the Lowry et al. method [35] after precipitation with $10 \%$ trichloracetic acid and solubilization with $1 \mathrm{~N} \mathrm{NaOH}$, using bovine serum albumin (BSA) as standard. The superoxide dismutase (SOD) activity was measured using the xanthine/xanthine oxidase system as the source of superoxide anions $\left(\mathrm{O}_{2}^{-}\right)$, detected by a solution of cytochrome $c$ in phosphate buffer ( $\mathrm{pH}$ 7.8). Moreover, it is commonly known in literature that SOD unity is defined as the amount of enzyme necessary to inhibit the reduction of cytochrome $c$ through xanthine-oxidase at a ratio of 50\% [36]. The peroxidase (POD) activity was determined at $470 \mathrm{~nm}$ and $30^{\circ} \mathrm{C}$ with guaiacol [37]. The sample of protein extract was treated with guaiacol and hydrogen peroxide disolved in $50 \mathrm{mM}$ citric acid/sodium phosphate buffer ( $\mathrm{pH}$ 5). In the presence of hydrogen peroxide, POD catalyzes the transformation of guaiacol to tetraguaiacol.

\section{Determination of Lipid Peroxide, Chlorophyll, and Carotenoid Content}

The concentration of malondialdehyde (MDA), obtained through decomposing the peroxides of polyunsaturated fatty acids, was determined by homogenizing 100 $\mathrm{mg}$ (d.w.) above-ground plant material in $4 \mathrm{ml}$ thiobarbituric acid (TBA) solution at 75,000 rpm for 30 seconds. The homogenized samples were centrifuged at $6,000 \mathrm{rpm}$ for 15 minutes at $4^{\circ} \mathrm{C}$, and the obtained supernatant was measured spectrophotometrically at 440,532 , and $600 \mathrm{~nm}$ [38]. The concentration of chlorophyll $a$ and $b$ and carotenoids was determined by homogenizing $30 \mathrm{mg}$ (d.w.) above-ground plant material in $80 \%$ acetone $(80 \%$ acetone: $15 \%$ water: $5 \%$ conc. $\mathrm{NH}_{3}$-solution [25\%], v/v) at 75,000 rpm for 30 seconds. After homogenization, the samples were centrifuged at $4,800 \mathrm{rpm}$ for 20 minutes at $4^{\circ} \mathrm{C}$, and the obtained supernatant was measured spectrophotometrically at 480, 645, 647, 663, and $664 \mathrm{~nm}$ for chlorophyll $a$, chlorophyll $b$, and carotenoids [39]. The assimilating pigments and lipid peroxides were determined from leaves.

\section{Statistical Analysis}

Data were analyzed using the Minitab statistical software package (version 16.0). In the interest of identifying the effect of pollution and inoculation with AMF on the biochemical variables of plants, the statistical test One-way ANOVA was used. With that purpose, multiple comparisons between variables of the three types of soil ( $\mathrm{U}-\mathrm{S}-\mathrm{C}_{1}$, U-S-C $\left.\mathrm{C}_{2}, \mathrm{U}-\mathrm{C}_{1}-\mathrm{C}_{1} \mathrm{I}, \mathrm{U}-\mathrm{C}_{2}-\mathrm{C}_{2} \mathrm{I}, \mathrm{S}-\mathrm{C}_{1}-\mathrm{C}_{1} \mathrm{I}, \mathrm{S}-\mathrm{C}_{2}-\mathrm{C}_{2} \mathrm{I}\right)$ were performed and the results depicted in tables and graphs. The assumption of normality was satisfied, which allowed us to carry out this statistical test. The first step was to find out whether the three groups did not all have the same mean value of the variables $(p<0.05)$. If that was the case, it was 
Table 2. Mycorrhization degree of Helianthus annuus L. root cortex at laboratory and field scales.

\begin{tabular}{|l|c|c|c|}
\hline Experimental variants & & $\mathrm{A} \%$ & $\mathrm{M} \%$ \\
\hline \multirow{2}{*}{$\mathrm{C}_{1} \mathrm{I}(\mathrm{n}=112)$} & $\bar{x}$ & 49.9 & 75.74 \\
\cline { 2 - 4 } & $s$ & 10.44 & 18.32 \\
\hline \multirow{2}{*}{$\mathrm{C}_{2} \mathrm{I}(\mathrm{n}=112)$} & $\bar{x}$ & 40.14 & 81.32 \\
\cline { 2 - 4 } & $s$ & 7.13 & 14.56 \\
\hline \multirow{2}{*}{$\mathrm{S}(\mathrm{n}=280)$} & $\bar{x}$ & 21.95 & 37.87 \\
\cline { 2 - 4 } & $s$ & 5.32 & 9.16 \\
\hline & Mann-Whitney U test \\
\hline $\mathrm{C}_{1} \mathrm{I}$ vs. $\mathrm{C}_{2} \mathrm{I}$ & $\mathrm{ns}$ & $\mathrm{ns}$ \\
\hline $\mathrm{C}_{1} \mathrm{I}$ vs. S & 0.016 & 0.043 \\
\hline $\mathrm{C}_{2} \mathrm{I}$ vs. S & 0.029 & 0.032 \\
\hline
\end{tabular}

$\mathrm{C}_{1} \mathrm{I}$ - contaminated inoculated soil $1, \mathrm{C}_{2} \mathrm{I}$ - contaminated inoculated soil 2, S - field soil, (M\%) - intensity of mycorrhizal colonization, (A\%) - abundance of arbuscules in the root system. ns - not significant

investigated where the differences lay by using Tukey's method. Tukey's method takes into consideration all possible pairwise differences of means at the same time. Ninetyfive percent confidence intervals were calculated showing the same results as the grouping. The effect of inoculation (variance of $\mathrm{A} \%$ and $\mathrm{M} \%$ ) was assessed by Mann-Whitney $\mathrm{U}$ test between artificially inoculated treatments and a natively inoculated one (at the significance level $\mathrm{p}<0.05$ ).

\section{Results and Discussion}

In the two artificially inoculated soils $\mathrm{C}_{1} \mathrm{I}$ and $\mathrm{C}_{2} \mathrm{I}$ we recorded an insignificant intensity of the mycorrhizal colonization $(\mathrm{M} \%)$ in the roots of plants grown on them (see Table 2). Moreover, no statistical differences were found between the abundances of arbuscules (A\%) of the two root cortices. If we compare $\mathrm{A} \%$ and $\mathrm{M} \%$ of the roots in $\mathrm{C}_{1} \mathrm{I}$ and $\mathrm{C}_{2} \mathrm{I}$ (lab scale, artificially inoculated) with those of the plants grown on $\mathrm{S}$ (field scale, natively inoculated), there were statistically significant differences in both cases. Although the plants were virtually the same age, they developed faster in field, reaching almost the same stage of aging, having available a much larger volume of soil and therefore greater amounts of nutrients. This statement is supported by the presence of flowers in plants from the field (data not shown). However, their AM root colonization in field was reduced probably due to a lower amount of native spores. It is documented that a larger amount of spores by artificial inoculation induces a larger degree of roots mycorrhization [40]. More recently, Zangaro et al. [41] demonstrated the same pattern of variation. They also reported that AM root colonization and spore density increase in the case of the early successional phase with the maintaining of a higher AM sporulation than the late suc- cessional species. In contrast to these reported results, Neagoe et al. [13] showed that larger amounts of spores by artificial inoculation had induced a lower degree of roots mycorrhization in field, but this seems to be a particular effect probably because of changes in the features of the substrate.

The $\mathrm{P}$ concentration in the three plant parts increased after artificial inoculation, and the highest concentrations were found in leaves, followed by shoots and roots (Table 3 ). A significant increase of the P concentration stood out in the three parts of the sunflower grown on a slightly contaminated and natively inoculated soil (S) compared to the contaminated and artificially inoculated soil $\left(\mathrm{C}_{1} \mathrm{I}, \mathrm{C}_{2} \mathrm{I}\right)$. It could be seen that in the field $(\mathrm{S})$ as a result of native inoculation, total $\mathrm{P}$ concentration in leaves of sunflower fitted very well in the range of $3,000-5,000 \mathrm{mg} \cdot \mathrm{kg}^{-1}$ considered optimal for plant development (according to Marschner [42]). This phenomenon can be explained on one hand by the fact that the soil is rich in nutrients as it is less polluted and, on the other hand, by the increased exploration surface of the root, which can assimilate larger quantities of nutrients. It is documented that the mycorrhizae are involved in nutrient transfer to the plant by increasing root surface, extending the nutrient depletion area around the root, and making phosphorus and nitrogen sources available to the plant [43]. Recently, Doubková et al. [44] found that inoculation improves plant growth and increases phosphorus uptake, which is in line with this result and our other previous results $[13,14]$.

Running the One-way ANOVA statistical test proved the existence of statistically significant differences between the P mean concentrations of the analyzed soil groups from the three plant parts, with some exceptions, as can be seen in Table 4. To the right of the Table 4, where we performed the One-way ANOVA grouping, some occurring pairs of letters can be seen and they have the following meaning: different letters indicate that the mean concentrations of the variables of the groups are significantly different. If the groups have a common letter, then there are no significant differences between the mean concentrations of the variables of these groups. Consequently, it can be seen that only in a few cases are there no significant differences between the mean concentrations of $\mathrm{P}$ in different soils for the three parts of the plants harvested. In the case of As, the root mean concentrations are significantly different between the soil pairs in grouping $\mathrm{U}-\mathrm{C}_{2}-\mathrm{C}_{2} \mathrm{I}$. For $\mathrm{Cr}$, statistically significant differences were found between the root mean concentrations of the soil pairs in grouping $\mathrm{U}-\mathrm{S}-\mathrm{C}_{2}$ and $\mathrm{S}_{-}-\mathrm{C}_{2}-$ $\mathrm{C}_{2} \mathrm{I}$, and in shoots and leaves between all the analyzed soil types except for the shoot mean concentrations in groups U- $\mathrm{C}_{2}-\mathrm{C}_{2} \mathrm{I}$ and $\mathrm{S}-\mathrm{C}_{2}-\mathrm{C}_{2} \mathrm{I}$. Between the analyzed soil pairs, we found significant differences in roots between $\mathrm{U}$ and $\mathrm{C}_{2}, \mathrm{~S}$ and $\mathrm{C}_{2}, \mathrm{~S}$ and $\mathrm{C}_{2} \mathrm{I}$, in shoots and leaves between $\mathrm{C}_{1}$ and $\mathrm{C}_{1} \mathrm{I}$, $\mathrm{U}$ and $\mathrm{C}_{2}, \mathrm{C}_{2}$ and $\mathrm{C}_{2} \mathrm{I}$, and between all the soil pairs in group U-S- $\mathrm{C}_{1}, \mathrm{~S}$ and $\mathrm{C}_{2}$ (except for $\mathrm{Cr}$ in shoots in soils $\mathrm{U}$ and $\mathrm{C}_{2}$, $\mathrm{C}_{2}$ and $\mathrm{C}_{2} \mathrm{I}, \mathrm{S}$ and $\mathrm{C}_{2}$ ).

As far as Mn is concerned, statistically significant differences were found in plant parts between all the analyzed 
Table 3. Element concentrations in plants.

\begin{tabular}{|c|c|c|c|c|c|c|c|c|c|}
\hline \multirow{2}{*}{ Variable } & & \multirow{2}{*}{$\begin{array}{c}\text { Parts of } \\
\text { plant }\end{array}$} & & \multicolumn{6}{|c|}{ Concentration of sunflower } \\
\hline & & & & $\mathrm{U}$ & $\mathrm{C}_{1}$ & $\mathrm{C}_{1} \mathrm{I}$ & $\mathrm{C}_{2}$ & $\mathrm{C}_{2} \mathrm{I}$ & S \\
\hline \multirow{6}{*}{ As } & \multirow{30}{*}{$\mu \mathrm{g} \cdot \mathrm{g}^{-1}$ d.w. } & \multirow{2}{*}{$\mathrm{R}$} & $\bar{x}$ & 0.567 & 1.826 & 2.403 & 5.789 & 1.883 & 0.402 \\
\hline & & & $s$ & 0.133 & 1.595 & 0.679 & 0.260 & 0.772 & 0.037 \\
\hline & & \multirow{2}{*}{$\mathrm{Sh}$} & $\bar{x}$ & BDL & BDL & BDL & BDL & BDL & 0.23 \\
\hline & & & $s$ & - & - & - & - & - & - \\
\hline & & \multirow{2}{*}{$\mathrm{L}$} & $\bar{x}$ & BDL & 0.400 & BDL & 0.131 & $\mathrm{BDL}$ & 0.201 \\
\hline & & & $s$ & - & 0.283 & - & 0.106 & - & 0.018 \\
\hline \multirow{6}{*}{$\mathrm{Cr}$} & & \multirow{2}{*}{$\mathrm{R}$} & $\bar{x}$ & 8.583 & 11.38 & 21.68 & 18.25 & 25.07 & 10.14 \\
\hline & & & $s$ & 2.444 & 15.78 & 23.13 & 5.759 & 13.04 & 3.100 \\
\hline & & \multirow{2}{*}{ Sh } & $\bar{x}$ & 0.627 & 1.085 & 0.442 & 1.365 & 1.900 & 0.427 \\
\hline & & & $s$ & 0.183 & 0.136 & 0.191 & 0.274 & 2.581 & 0.048 \\
\hline & & \multirow{2}{*}{$\mathrm{L}$} & $\bar{x}$ & 6.229 & 10.76 & 4.255 & 13.31 & 5.908 & 4.120 \\
\hline & & & $s$ & 1.733 & 1.476 & 1.766 & 2.870 & 1.583 & 1.151 \\
\hline \multirow{6}{*}{$\mathrm{Mn}$} & & \multirow{2}{*}{$\mathrm{R}$} & $\bar{x}$ & 268.4 & 428.0 & 239.6 & 226.5 & 484.0 & 162.8 \\
\hline & & & $s$ & 58.68 & 273.4 & 83.08 & 189.8 & 269.8 & 38.90 \\
\hline & & \multirow{2}{*}{ Sh } & $\bar{x}$ & 17.19 & 67.65 & 45.52 & 129.4 & 54.61 & 13.14 \\
\hline & & & $s$ & 5.255 & 12.47 & 4.921 & 16.72 & 19.14 & 2.382 \\
\hline & & \multirow{2}{*}{$\mathrm{L}$} & $\bar{x}$ & 163.1 & 657.8 & 454.6 & 1291 & 545.0 & 175.7 \\
\hline & & & $s$ & 40.36 & 108.9 & 51.30 & 169.1 & 190.0 & 53.72 \\
\hline \multirow{6}{*}{$\mathrm{Ni}$} & & \multirow{2}{*}{$\mathrm{R}$} & $\bar{x}$ & 21.70 & 38.50 & 43.32 & 95.10 & 57.66 & 9.590 \\
\hline & & & $s$ & 4.137 & 25.81 & 5.061 & 17.00 & 20.11 & 1.492 \\
\hline & & \multirow{2}{*}{$\mathrm{Sh}$} & $\bar{x}$ & 7.822 & 14.11 & 9.615 & 19.42 & 8.479 & 11.65 \\
\hline & & & $s$ & 0.705 & 0.898 & 0.842 & 4.589 & 2.542 & 2.426 \\
\hline & & \multirow{2}{*}{$\mathrm{L}$} & $\bar{x}$ & 12.79 & 19.06 & 14.54 & 24.05 & 13.01 & 12.44 \\
\hline & & & $s$ & 0.835 & 0.965 & 0.806 & 4.520 & 2.195 & 0.312 \\
\hline \multirow{6}{*}{$\mathrm{P}$} & & \multirow{2}{*}{$\mathrm{R}$} & $\bar{x}$ & 2618 & 950.4 & 1202 & 843.3 & 1124 & 1334 \\
\hline & & & $s$ & 47.77 & 145.1 & 137.8 & 97.34 & 147.6 & 327.0 \\
\hline & & \multirow{2}{*}{ Sh } & $\bar{x}$ & 3512 & 1263 & 1635 & 1124 & 1403 & 2070 \\
\hline & & & $s$ & 432 & 288 & 266 & 68 & 190 & 448 \\
\hline & & \multirow{2}{*}{$\mathrm{L}$} & $\bar{x}$ & 4332 & 1884 & 2483 & 1741 & 2040 & 3391 \\
\hline & & & $s$ & 930 & 239 & 142 & 68 & 489 & 660.8 \\
\hline
\end{tabular}

L - leaves, Sh - shoots, $R$ - roots, $U$ - uncontaminated soil, $C_{1}$ - contaminated soil 1, $C_{2}-$ contaminated soil $2, C_{1} I-$ contaminated inoculated soil 1, $\mathrm{C}_{2} \mathrm{I}$ - contaminated inoculated soil 2, $\mathrm{S}$ - field soil.

$\mathrm{BDL}$ - below detection limit $\left(0.48 \mathrm{ng} \cdot \mathrm{kg}^{-1}\right.$ for As)

soil groups, except for $\mathrm{Mn}$ in roots in groups $\mathrm{U}_{-} \mathrm{C}_{1}-\mathrm{C}_{1} \mathrm{I}$, U$\mathrm{C}_{2}-\mathrm{C}_{2} \mathrm{I}$, and U-S- $\mathrm{C}_{2}$, which was also confirmed by the A-AA grouping that shows there is no evidence of differences between mean concentrations. Soil pair analysis showed significant differences between the Mn mean concentrations in roots in soils $\mathrm{S}$ and $\mathrm{C}_{1}, \mathrm{~S}$ and $\mathrm{C}_{2} \mathrm{I}$, and in shoots and leaves between all soil pairs in groups $\mathrm{U}_{-} \mathrm{C}_{1}-\mathrm{C}_{1} \mathrm{I}, \mathrm{U}-\mathrm{C}_{2}-\mathrm{C}_{2} \mathrm{I}, \mathrm{S}-$ $\mathrm{C}_{1}-\mathrm{C}_{1} \mathrm{I}, \mathrm{S}-\mathrm{C}_{2}-\mathrm{C}_{2} \mathrm{I}$. In the case of $\mathrm{Ni}$, significant differences between the mean concentrations in plant parts were found between all the analyzed soil groups, except for the $\mathrm{Ni}$ in roots in group $\mathrm{U}-\mathrm{C}_{1}-\mathrm{C}_{1} \mathrm{I}$. P values $<0.05$ were registered in roots between soil pairs in groupings $\mathrm{U}-\mathrm{C}_{2}-\mathrm{C}_{2} \mathrm{I}, \mathrm{S}-\mathrm{C}_{2}-\mathrm{C}_{2} \mathrm{I}$, and 


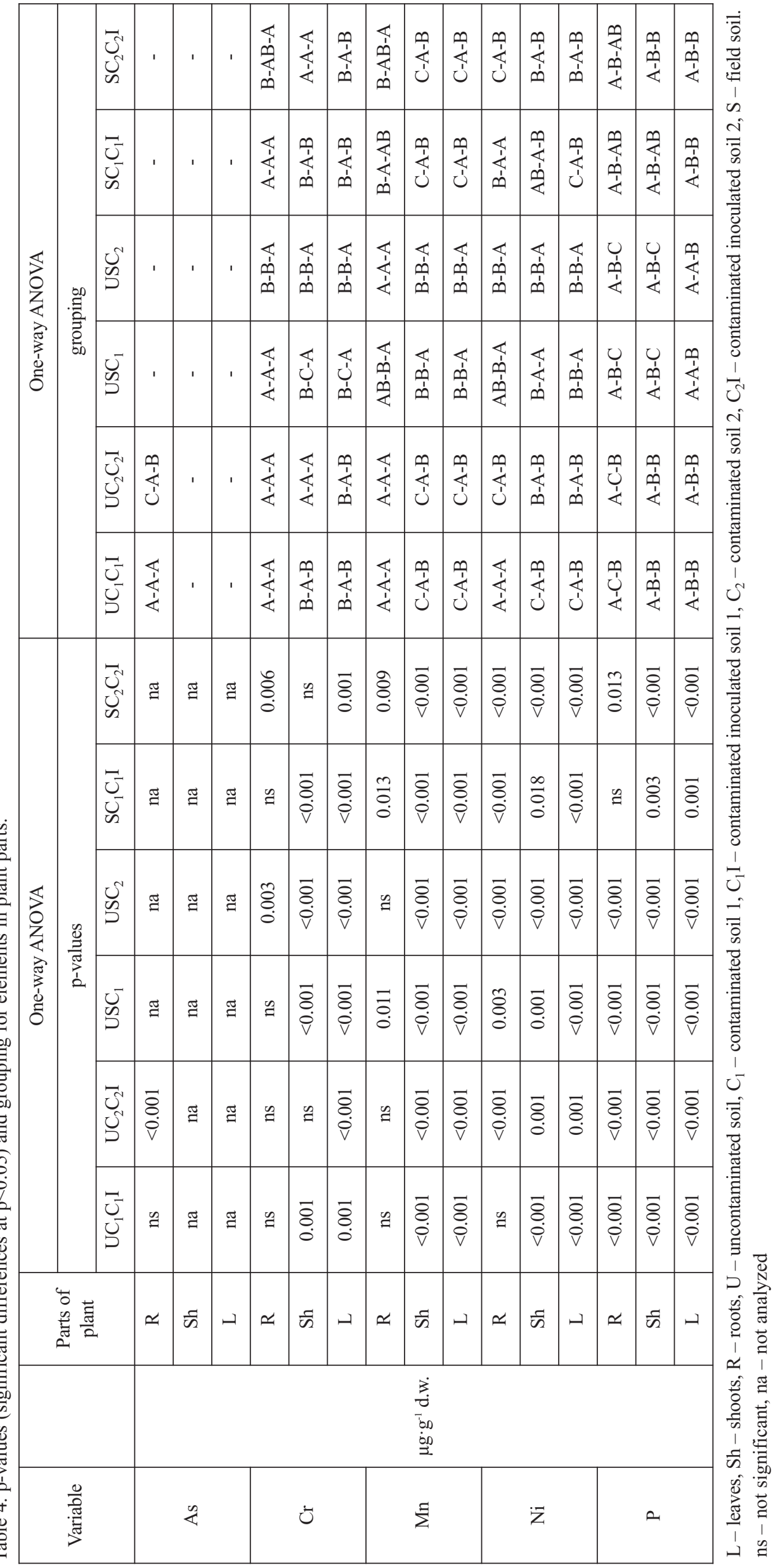


Table 5. Translocation coefficients (TC) of elements from roots to above-ground part of sunflower parts.

\begin{tabular}{|c|c|c|c|c|c|c|}
\hline \multirow{2}{*}{ Variable } & \multicolumn{7}{|c|}{ TC of elements } & \multicolumn{2}{c|}{$\mathrm{C}_{2} \mathrm{I}$} & $\mathrm{S}$ \\
\cline { 2 - 7 } & $\mathrm{U}$ & $\mathrm{C}_{1}$ & $\mathrm{C}_{1} \mathrm{I}$ & $\mathrm{C}_{2}$ & $\mathrm{na}$ & 1.072 \\
\hline $\mathrm{As}$ & $\mathrm{na}$ & 0.218 & $\mathrm{BDL}$ & 0.022 & 0.311 & 0.687 \\
\hline $\mathrm{Cr}$ & 0.798 & 1.041 & 0.216 & 0.804 & 1.239 & 1.170 \\
\hline $\mathrm{Mn}$ & 0.671 & 1.695 & 2.086 & 6.273 & 0.372 & 0.878 \\
\hline $\mathrm{Ni}$ & 0.950 & 0.861 & 0.557 & 0.457 & 3.060 & 4.093 \\
\hline $\mathrm{P}$ & 2.996 & 3.311 & 3.425 & 3.397 & & \\
\hline
\end{tabular}

$\mathrm{U}$ - uncontaminated soil, $\mathrm{C}_{1}$ - contaminated soil $1, \mathrm{C}_{1} \mathrm{I}$ - contaminated inoculated soil $1, \mathrm{C}_{2}$ - contaminated soil 2 , $\mathrm{C}_{2} \mathrm{I}-$ contaminated inoculated soil $2, \mathrm{~S}-$ field soil.

na - not analyzed, measured values below detection limit, BDL - below detection limit ( $0.48 \mathrm{ng} \cdot \mathrm{kg}^{-1}$ for As)

also $\mathrm{S}$ and $\mathrm{C}_{1}, \mathrm{~S}$ and $\mathrm{C}_{1} \mathrm{I}$. It was noticed that the mean concentrations in shoots and leaves were different between the soil pairs in groupings $\mathrm{U}_{-} \mathrm{C}_{1}-\mathrm{C}_{1} \mathrm{I}, \mathrm{S}-\mathrm{C}_{1}-\mathrm{C}_{1} \mathrm{I}, \mathrm{U}$ and $\mathrm{C}_{2}, \mathrm{C}_{2}$ and $\mathrm{C}_{2} \mathrm{I}, \mathrm{U}$ and $\mathrm{S}, \mathrm{S}$ and $\mathrm{C}_{2}$, with the exception of the $\mathrm{Ni}$ in shoots for soils $\mathrm{S}$ and $\mathrm{C}_{1}$, and in leaves for $\mathrm{U}$ and $\mathrm{S}$ (Table 4).

In order to check the translocation of the root elements in the aboveground parts we computed the transfer coefficients (TC) and we found that artificial inoculation had reduced $\mathrm{As}, \mathrm{Cr}$, and $\mathrm{Ni}$ translocation from roots to shoots and leaves, probably because of lower concentrations of elements with toxic potential in soil and higher P concentrations (Table 5). Our results are consistent with the literature, such as the one published by Zhao et al. [45]. This author highlighted the role of mycorrhization in protecting the plants against As toxicity and possibly in limiting the transfer of As from roots to shoots. Our research showed that the native or artificial inoculation of soils with mycorrhizal fungi had reduced the availability of metals and metalloids with toxic potential (As, Cr, Mn, Ni) for the sunflower species grown in lab and in field.

The faster development of sunflower in field was confirmed by a higher biomass, as can be seen in Table 6 . All three investigated plant parts recorded a significantly higher biomass in $\mathrm{S}$ (natively inoculated) in comparison to $\mathrm{C}_{1}$ and $\mathrm{C}_{2}$ followed by $\mathrm{U}$ (sterilized). A higher intensity of mycorrhizal colonization $(\mathrm{M} \%)$ in roots of sunflower grown on $\mathrm{C}_{2} \mathrm{I}$ compared to those grown on $\mathrm{C}_{1} \mathrm{I}$ explains the significant biomass increase in all plant parts and the total biomass grown on $\mathrm{C}_{2} \mathrm{I}$ compared to $\mathrm{C}_{1} \mathrm{I}$. However, these biomasses (harvested from $\mathrm{C}_{1} \mathrm{I}$ and $\mathrm{C}_{2} \mathrm{I}$ treatments) were lower compared to those obtained from plants grown on $\mathrm{U}$, in the absence of inoculation. All three plant parts and the total biomass presented statistically significant differences between the mean biomass grown on the three types of soil $(p<0.05)$. We also performed grouping analysis to establish between which biomass grown on soil pairs these differences existed. So, for plant biomass grown on soils $U$ and $\mathrm{C}_{1}$, and $\mathrm{U}$ and $\mathrm{C}_{2}$, there were statistically significant differences in shoots and leaves and in roots only between $\mathrm{U}$ and $\mathrm{C}_{2}$. In the case of soils $\mathrm{U}$ and $\mathrm{S}, \mathrm{S}$ and $\mathrm{C}_{1}, \mathrm{~S}$ and $\mathrm{C}_{2}, \mathrm{~S}$ and $\mathrm{C}_{1} \mathrm{I}, \mathrm{S}$ and $\mathrm{C}_{2} \mathrm{I}$, statistically significant differences were found between all harvested plant parts including the total biomass (Table 7). In conclusion, the highest biomass production was in plants grown in field, even if the plants grown in the lab were the same age. In contrast with higher biomasses, variables such as chlorophyll ( $a$ and $b$ ) and carotenoids content presented a different pattern of variations. These variables recorded statistically lower chlorophyll and carotenoid contents, which reflects the existence of more mature plants in the field (Table 6). Statistically significant differences were found between the mean concentrations of the assimilating pigments ( $\mathrm{chl} a, \operatorname{chl} b$, carotenoids) in leaves, and between plants grown on the three types of soil, except for the carotenoids measured in plants grown in group $\mathrm{U}-\mathrm{C}_{1}-\mathrm{C}_{1} \mathrm{I}$, which was also confirmed by the A-A-A grouping that showed there was no evidence of differences between mean concentrations. Moreover, in the case of $\operatorname{chl} a$, the A-C-B grouping indicated differences between the mean concentrations of all the analyzed soil pairs. For chl $b$ and carotenoids, statistically significant differences were found between plants grown on soils $\mathrm{C}_{1}$ and $\mathrm{C}_{1} \mathrm{I}, \mathrm{C}_{2}$ and $\mathrm{C}_{2} \mathrm{I}, \mathrm{U}$ and $\mathrm{C}_{2}, \mathrm{U}$ and $\mathrm{S}, \mathrm{S}$ and $\mathrm{C}_{1}, \mathrm{~S}$ and $\mathrm{C}_{1} \mathrm{I}$, and $\mathrm{S}$ and $\mathrm{C}_{2} \mathrm{I}$, to which soils $\mathrm{S}$ and $\mathrm{C}_{2}$ are added in the case of carotenoids (Table 7). Our results concerning the decrease of assimilating pigments along with plant aging are in agreement with those obtained by many other authors. For instance, Sedigheh et al. [46] found differences in the rate of photosynthesis that significantly decreased with the increasing of the plant age. Also Christ and Hörtensteiner [47] demonstrated that chlorophyll breakdown is the most obvious sign of leaf senescence. On the other hand, the colonization of roots by Glomus intraradices significantly improved chlorophyll ( $a$ and $b$ ) and carotenoid content, our results being in accordance with Abdel Latef [48].

A similar pattern of variations were also found in the case of non-enzymatic lipid peroxidation estimated by determining the MDA concentration. The content of the MDA measured in leaves tended to decrease under low heavy metal stress (the case of plants grown on $\mathrm{U}$ and $\mathrm{S}$, followed by $\mathrm{C}_{1} \mathrm{I}$ and $\mathrm{C}_{2} \mathrm{I}$ ) as a positive effect of mycorrhization (Table 6). Statistically significant differences were found between the mean concentrations of the LP in leaves, 
Table 6. Biochemical variables of plants.

\begin{tabular}{|c|c|c|c|c|c|c|c|c|}
\hline \multirow{2}{*}{ Variable } & \multirow{2}{*}{$\begin{array}{l}\text { Parts of } \\
\text { plant }\end{array}$} & & \multicolumn{6}{|c|}{ Concentration of elements in sunflower } \\
\hline & & & $\mathrm{U}$ & $\mathrm{C}_{1}$ & $\mathrm{C}_{1} \mathrm{I}$ & $\mathrm{C}_{2}$ & $\mathrm{C}_{2} \mathrm{I}$ & $\mathrm{S}$ \\
\hline \multirow{8}{*}{$\begin{array}{l}\text { Biomass } \\
\mathrm{mg} \cdot \mathrm{g}^{-1} \mathrm{~d} . \mathrm{w} .\end{array}$} & \multirow{2}{*}{$\mathrm{L}$} & $\bar{x}$ & 2.148 & 1.135 & 1.333 & 1.078 & 1.393 & 5.724 \\
\hline & & $s$ & 0.343 & 0.165 & 0.107 & 0.048 & 0.189 & 1.994 \\
\hline & \multirow{2}{*}{ Sh } & $\bar{x}$ & 2.593 & 1.165 & 1.345 & 1.26 & 1.825 & 14.21 \\
\hline & & $s$ & 0.191 & 0.053 & 0.26 & 0.098 & 0.454 & 5.063 \\
\hline & \multirow{2}{*}{$\mathrm{R}$} & $\bar{x}$ & 1.053 & 0.71 & 1.06 & 0.583 & 1.025 & 3.887 \\
\hline & & $s$ & 0.071 & 0.375 & 0.061 & 0.266 & 0.104 & 1.598 \\
\hline & \multirow{2}{*}{$\mathrm{T}$} & $\bar{x}$ & 5.793 & 3.010 & 3.738 & 2.920 & 4.243 & 23.82 \\
\hline & & $s$ & 0.449 & 0.505 & 0.379 & 0.302 & 0.676 & 8.446 \\
\hline \multirow{6}{*}{$\begin{array}{l}\text { Chl, Carot } \\
\mu \mathrm{g} \cdot \mathrm{g}^{-1} \text { d.w. }\end{array}$} & \multirow{2}{*}{$\mathrm{L} \operatorname{chl} a$} & $\bar{x}$ & 13.28 & 6.385 & 9.292 & 6.824 & 10.55 & 4.547 \\
\hline & & $s$ & 0.494 & 0.36 & 0.383 & 0.298 & 0.471 & 0.748 \\
\hline & \multirow{2}{*}{$\mathrm{L} \operatorname{chl} b$} & $\bar{x}$ & 4.88 & 4.925 & 5.594 & 1.457 & 3.621 & 1.346 \\
\hline & & $s$ & 2.206 & 0.172 & 0.940 & 0.093 & 0.704 & 0.246 \\
\hline & \multirow{2}{*}{ L car } & $\bar{x}$ & 0.433 & 0.381 & 0.456 & 0.148 & 0.419 & 0.204 \\
\hline & & $s$ & 0.072 & 0.013 & 0.021 & 0.022 & 0.039 & 0.024 \\
\hline \multirow{2}{*}{$\begin{array}{c}\mathrm{LP} \\
\mu \mathrm{M} \mathrm{MDA}^{-\mathrm{g}^{-1}} \text { d.w. }\end{array}$} & \multirow{2}{*}{$\mathrm{L}$} & $\bar{x}$ & 0.464 & 0.643 & 0.505 & 0.694 & 0.542 & 0.297 \\
\hline & & $s$ & 0.053 & 0.038 & 0.032 & 0.028 & 0.002 & 0.043 \\
\hline \multirow{6}{*}{$\begin{array}{l}\text { Proteins } \\
\mu \mathrm{g} \cdot \mathrm{g}^{-1} \text { d.w. }\end{array}$} & \multirow{2}{*}{$\mathrm{L}$} & $\bar{x}$ & 6270 & 2329 & 2703 & 999.5 & 1626 & 28117 \\
\hline & & $s$ & 357.2 & 186.8 & 327.8 & 83.18 & 505.9 & 3707 \\
\hline & \multirow{2}{*}{ Sh } & $\bar{x}$ & 2534 & 1450 & 2488 & 1419 & 1810 & 2671 \\
\hline & & $s$ & 72.71 & 226.0 & 692.7 & 178.2 & 383.3 & 179.7 \\
\hline & \multirow{2}{*}{$\mathrm{R}$} & $\bar{x}$ & 111.6 & 26.21 & 36.39 & 38.53 & 52.39 & 237.2 \\
\hline & & $s$ & 4.539 & 3.269 & 2.485 & 7.872 & 4.297 & 65.96 \\
\hline \multirow{6}{*}{$\begin{array}{c}\mathrm{SOD} \\
\mathrm{U} \cdot \mathrm{mg}^{-1} \text { protein }\end{array}$} & \multirow{2}{*}{$\mathrm{L}$} & $\bar{x}$ & 90.81 & 227.4 & 139.5 & 310.2 & 135.4 & 162.4 \\
\hline & & $s$ & 12.45 & 64.01 & 17.62 & 38.61 & 20.42 & 66.82 \\
\hline & \multirow{2}{*}{ Sh } & $\bar{x}$ & 39.04 & 69.84 & 46.11 & 77.31 & 55.99 & 20.24 \\
\hline & & $s$ & 4.476 & 6.044 & 4.874 & 7.454 & 4.542 & 4.464 \\
\hline & \multirow{2}{*}{$\mathrm{R}$} & $\bar{x}$ & 137.7 & 608.9 & 416.5 & 716 & 553.3 & 313.7 \\
\hline & & $s$ & 17.90 & 45.17 & 48.44 & 65.75 & 23.27 & 251.7 \\
\hline \multirow{6}{*}{$\begin{array}{c}\text { POD } \\
\mu \mathrm{U} \cdot \mathrm{mg}^{-1} \text { protein }\end{array}$} & \multirow{2}{*}{$\mathrm{L}$} & $\bar{x}$ & 0.853 & 1.685 & 1.134 & 2.008 & 1.338 & 1.433 \\
\hline & & $s$ & 0.074 & 0.195 & 0.133 & 0.097 & 0.430 & 0.289 \\
\hline & \multirow{2}{*}{ Sh } & $\bar{x}$ & 0.426 & 1.143 & 0.844 & 1.537 & 0.922 & 0.436 \\
\hline & & $s$ & 0.074 & 0.187 & 0.085 & 0.342 & 0.152 & 0.138 \\
\hline & \multirow{2}{*}{$\mathrm{R}$} & $\bar{x}$ & 0.944 & 2.871 & 2.043 & 2.043 & 1.391 & 0.516 \\
\hline & & $s$ & 0.104 & 0.191 & 0.165 & 0.164 & 0.296 & 0.326 \\
\hline
\end{tabular}

$\mathrm{U}$ - uncontaminated soil, $\mathrm{C}_{1}$ - contaminated soil $1, \mathrm{C}_{1} \mathrm{I}$ - contaminated inoculated soil $1, \mathrm{C}_{2}$ - contaminated soil 2 , $\mathrm{C}_{2} \mathrm{I}-$ contaminated inoculated soil 2, S - field soil, L - leaves, Sh - shoots, R - roots, T - total biomass, Chl - chlorophyll $a$ and $b$, Carot - carotenoids, LP - lipid peroxides, MDA - malondialdehyde. 
Table 7. p-values (significant differences at $\mathrm{p}<0.05$ ) and grouping for elements in plant parts.

\begin{tabular}{|c|c|c|c|c|c|c|c|c|c|c|c|c|c|}
\hline \multirow{3}{*}{ Variable } & \multirow{3}{*}{$\begin{array}{l}\text { Parts } \\
\text { of } \\
\text { plant }\end{array}$} & \multicolumn{6}{|c|}{ One-way ANOVA } & \multicolumn{6}{|c|}{ One-way ANOVA } \\
\hline & & \multicolumn{6}{|c|}{ p-values } & \multicolumn{6}{|c|}{ grouping } \\
\hline & & $\mathrm{UC}_{1} \mathrm{C}_{1} \mathrm{I}$ & $\mathrm{UC}_{2} \mathrm{C}_{2} \mathrm{I}$ & $\mathrm{USC}_{1}$ & $\mathrm{USC}_{2}$ & $\mathrm{SC}_{1} \mathrm{C}_{1} \mathrm{I}$ & $\mathrm{SC}_{2} \mathrm{C}_{2} \mathrm{I}$ & $\mathrm{UC}_{1} \mathrm{C}_{1} \mathrm{I}$ & $\mathrm{UC}_{2} \mathrm{C}_{2} \mathrm{I}$ & $\mathrm{USC}_{1}$ & $\mathrm{USC}_{2}$ & $\mathrm{SC}_{1} \mathrm{C}_{1} \mathrm{I}$ & $\mathrm{SC}_{2} \mathrm{C}_{2} \mathrm{I}$ \\
\hline \multirow{4}{*}{$\begin{array}{l}\text { Biomass } \\
\mathrm{mg} \cdot \mathrm{g}^{-1} \mathrm{~d} . \mathrm{w} .\end{array}$} & $\mathrm{R}$ & NS* & 0.006 & 0.001 & $<0.001$ & 0.001 & $<0.001$ & A-A-A & A-B-A & B-A-B & B-A-B & A-B-B & A-B-B \\
\hline & Sh & $<0.001$ & $<0.001$ & $<0.001$ & $<0.001$ & $<0.001$ & $<0.001$ & A-B-B & A-B-B & B-A-B & B-A-B & A-B-B & A-B-B \\
\hline & $\mathrm{L}$ & $<0.001$ & $<0.001$ & $<0.001$ & $<0.001$ & $<0.001$ & $<0.001$ & A-B-B & A-B-B & B-A-B & B-A-B & A-B-B & A-B-B \\
\hline & $\mathrm{T}$ & $<0.001$ & $<0.001$ & $<0.001$ & $<0.001$ & $<0.001$ & $<0.001$ & A-B-B & A-C-B & B-A-B & B-A-B & A-B-B & A-B-B \\
\hline \multirow{3}{*}{$\begin{array}{l}\text { Chl, Carot } \\
\mu \mathrm{g} \cdot \mathrm{g}^{-1} \text { d.w. }\end{array}$} & L chl a & $<0.001$ & $<0.001$ & $<0.001$ & $<0.001$ & $<0.001$ & $<0.001$ & A-C-B & A-C-B & A-C-B & A-C-B & C-B-A & C-B-A \\
\hline & $\mathrm{L}$ chl b & 0.026 & 0.017 & $<0.001$ & $<0.001$ & $<0.001$ & $<0.001$ & A-A-B & A-B-AB & A-B-A & A-B-B & C-A-B & B-B-A \\
\hline & L car & NS & $<0.001$ & $<0.001$ & $<0.001$ & $<0.001$ & $<0.001$ & A-A-A & A-B-A & A-B-A & A-B-B & C-B-A & B-C-A \\
\hline $\begin{array}{c}\text { LP } \\
\mu \mathrm{M} \text { MDA.g }{ }^{-1} \\
\text { d.w. }\end{array}$ & L & 0.001 & $<0.001$ & $<0.001$ & $<0.001$ & $<0.001$ & $<0.001$ & B-A-B & C-A-B & B-C-A & B-C-A & C-A-B & C-A-B \\
\hline \multirow{3}{*}{$\begin{array}{l}\text { Proteins } \\
\mu \mathrm{g} \cdot \mathrm{g}^{-1} \text { d.w. }\end{array}$} & $\mathrm{R}$ & $<0.001$ & $<0.001$ & $<0.001$ & $<0.001$ & $<0.001$ & $<0.001$ & A-C-B & A-C-B & B-A-B & B-A-B & A-B-B & A-B-B \\
\hline & Sh & 0.009 & $<0.001$ & $<0.001$ & $<0.001$ & $<0.001$ & $<0.001$ & A-B-A & A-B-B & A-A-B & A-A-B & A-B-A & A-B-B \\
\hline & $\mathrm{L}$ & $<0.001$ & $<0.001$ & $<0.001$ & $<0.001$ & $<0.001$ & $<0.001$ & A-B-B & A-B-B & B-A-B & B-A-B & A-B-B & A-B-B \\
\hline \multirow{3}{*}{$\begin{array}{c}\text { SOD } \\
\mathrm{U} \cdot \mathrm{mg}^{-1} \\
\text { protein }\end{array}$} & $\mathrm{R}$ & $<0.001$ & $<0.001$ & 0.002 & 0.013 & 0.009 & NS & C-A-B & C-A-B & B-B-A & B-AB-A & B-A-AB & A-A-A \\
\hline & Sh & $<0.001$ & $<0.001$ & $<0.001$ & $<0.001$ & $<0.001$ & $<0.001$ & B-A-B & C-A-B & B-C-A & B-C-A & C-A-B & C-A-B \\
\hline & $\mathrm{L}$ & 0.002 & $<0.001$ & 0.018 & $<0.001$ & NS & 0.001 & B-A-B & B-A-B & B-AB-A & B-B-A & A-A-A & B-A-B \\
\hline \multirow{3}{*}{$\begin{array}{c}\text { POD } \\
\mu \mathrm{U} \cdot \mathrm{mg}^{-1} \\
\text { protein }\end{array}$} & $\mathrm{R}$ & $<0.001$ & $<0.001$ & $<0.001$ & $<0.001$ & $<0.001$ & $<0.001$ & C-A-B & B-A-B & B-C-A & B-B-A & C-A-B & C-A-B \\
\hline & Sh & $<0.001$ & $<0.001$ & $<0.001$ & $<0.001$ & $<0.001$ & $<0.001$ & C-A-B & C-A-B & B-B-A & B-B-A & C-A-B & C-A-B \\
\hline & $\mathrm{L}$ & $<0.001$ & $<0.001$ & 0.001 & $<0.001$ & 0.022 & 0.009 & B-A-B & B-A-B & B-A-A & C-B-A & AB-A-B & B-A-B \\
\hline
\end{tabular}

$\mathrm{U}$ - uncontaminated soil, $\mathrm{C}_{1}$ - contaminated soil 1, $\mathrm{C}_{1} \mathrm{I}$ - contaminated inoculated soil 1, $\mathrm{C}_{2}$ - contaminated soil 2, $\mathrm{C}_{2} \mathrm{I}-$ contaminated inoculated soil 2, $\mathrm{S}$ - field soil, $\mathrm{L}$ - leaves, $\mathrm{Sh}$ - shoots, $\mathrm{R}$ - roots, $\mathrm{T}$ - total biomass, Chl - chlorophyll $a$ and $b$, Carot - carotenoids, LP - lipid peroxides

*NS - not significant

and between the plants grown on the three types of soil, according to the C-A-B grouping except for those grown on soils $\mathrm{U}$ and $\mathrm{C}_{1} \mathrm{I}$ (Table 7). In agreement with our results, Contreras et al. [49], Jouili et al. [50], and Arunakumara et al. [51] demonstrated that, when the concentration of HM is changed, the plants produce a different content of lipid peroxidation, which leads to the damage of the biological molecules. In conclusion, the excess of metals involves the induction of lipid peroxidation in plants, which causes the degradation of lipoprotein membrane by lipid peroxidation, which could also include the degradation of photosynthetic pigments, causing deterioration in growth [52]. The presence of stress-tolerant mycorrhyzal fungi could reduce MDA content according to González-Guerrero et al. [53] and Abdel Latef [48]. Positive effects of natural inoculation can be seen in protein content, which is huge in comparison with all other treatments. The positive effect of artificial inoculation manifested itself in all three plant parts in both $\mathrm{C}_{1} \mathrm{I}$ and $\mathrm{C}_{2} \mathrm{I}$ treatments. Statistically significant differences were pointed out by comparing the mean concentrations of proteins, SOD and POD, between plants grown on the three types of soil analyzed, with the exception of SOD in leaves for group $\mathrm{S}^{-} \mathrm{C}_{1}-\mathrm{C}_{1} \mathrm{I}$, and in roots for group $\mathrm{S}-\mathrm{C}_{2}-\mathrm{C}_{2} \mathrm{I}$.

Also, statistically significant differences were identified in the SOD activity in roots between plants grown on all soil pairs in groups $\mathrm{U}-\mathrm{C}_{1}-\mathrm{C}_{1} \mathrm{I}$ and $\mathrm{U}-\mathrm{C}_{2}-\mathrm{C}_{2} \mathrm{I}$. Protein and $\mathrm{POD}$ concentrations in roots presented the same variation pattern except for the POD in roots for plants grown on soils $\mathrm{U}$ and $\mathrm{C}_{2} \mathrm{I}$. In addition, there were statistically significant differences between the protein mean concentrations in the three plant parts in groups $\mathrm{S}-\mathrm{C}_{1}-\mathrm{C} 1 \mathrm{I}$ and $\mathrm{S}_{-} \mathrm{C}_{2}-\mathrm{C}_{2} \mathrm{I}$ for soils $\mathrm{S}$ and $\mathrm{C}_{1}, \mathrm{~S}$ and $\mathrm{C}_{1} \mathrm{I}, \mathrm{S}$ and $\mathrm{C}_{2}$, and $\mathrm{S}$ and $\mathrm{C}_{2} \mathrm{I}$ (except for the protein mean concentrations in shoots, which are not different in soils $\mathrm{S}$ and $\mathrm{C}_{1} \mathrm{I}$ ). Statistically significant differences between mean concentrations were pointed out by comparing SOD and POD activity in shoots between plants grown on all soil pairs in the analyzed groups, with the exception of SOD activity in shoots grown on soils $U$ and $\mathrm{C}_{1} \mathrm{I}$, and the POD activity in shoots grown on in soils $\mathrm{U}$ and $\mathrm{S}$. As expected, enzyme activity registered the highest value in roots, followed by leaves and shoots, the order of the 
enzyme activity increase being: $\mathrm{U}<\mathrm{S}<\mathrm{C}_{1} \mathrm{I}<\mathrm{C}_{2} \mathrm{I}<\mathrm{C}_{1}<\mathrm{C}_{2}$. This is the order of pollution increase, too, similar results also being published by González-Guerrero et al. [53] and, Neagoe et al. [13, 14].

What is interesting, in contrast with very contaminated substrates such as mine tailings [12-14], is that the response of oxidative stress variables for plants grown in unpolluted or slightly polluted soils presents similar patterns of variation in almost all plant parts. However, plants benefit from the effect of mycorrhizal fungi even in such substrates because the fungi enhance drought resistance in them [17, 54]. Also, Clemens [7] states that HM stress up-regulates SOD and POD, but that high metal concentrations in plants can also lower the activity of these enzymes either through binding and direct inactivation, or through glutathione consumption. In the case of our results, a strong argument that supports this pattern of variation of plant biochemical variables consists in the element concentration changes found at leaf level (Fig. 1). In leaves, the concentrations of the elements that interested us in this study (As, $\mathrm{Cr}, \mathrm{Mn}, \mathrm{Ni}$ ) presented a significant decrease and they were even absent in some cases (registered under detection limits namely, $<0.1-1 \mathrm{ng} \cdot \mathrm{kg}^{-1}$ in the case of As for native $\mathrm{S}$ and artificial $\mathrm{C}_{1} \mathrm{I}$ and $\mathrm{C}_{2} \mathrm{I}$ inoculation, and as it was expected in $\mathrm{U}$ ), as a positive outcome of soil inoculation. So, AM fungi protect plants from toxic elements by retaining them in their root systems, and they also have the potential to change and modify the rhizosphere environment, which acts as a nutri-

As - leaves at pot and field scales

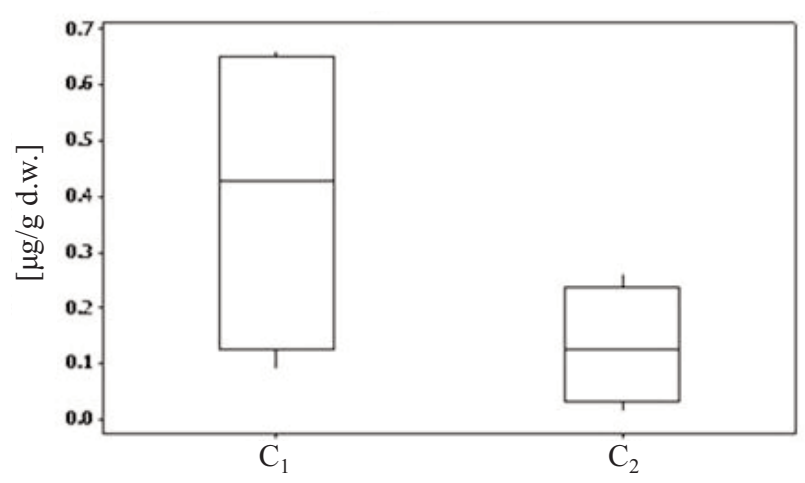

$\mathrm{Ni}$ - leaves at pot and field scales

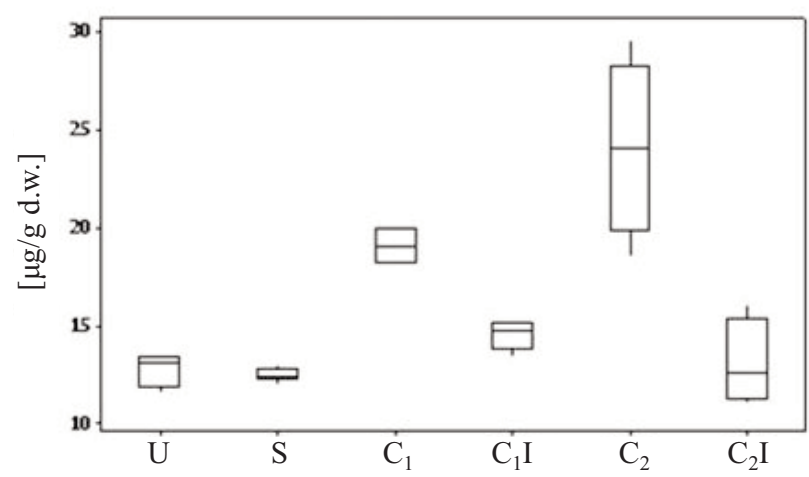

ent source for the microorganisms in plant root region (mycorrhizosphere). These statements are also very well documented by many other authors [12-14, 29, 55, 56].

\section{Conclusions}

In line with our prediction, the biomass production presented a different pattern of variation between scales, registering a significantly higher production in field than in lab. As a consequence, we expected to find a lower oxidative stress in the plants better developed at field scale. However, contrary to our expectations, the plants in field registered a higher oxidative stress. This result can be explained by obtaining a total mycorrhizal colonization and arbuscular abundance significantly lower in the root system of sunflowers grown at field scale, in comparison with that grown at lab artificially inoculated scale. Consequently, this phenomenon was reflected in the intensification of the oxidative stress response in all plant parts at field scale. However, the second hypothesis was also confirmed, as we found similar patterns of the plant biochemical variables, for the same plant parts, both at lab and field scales, which reinforce our belief that these variables could be used as environmental biomarkers for soils with moderate pollution. A knowledge gap still remains concerning the in situ influences of HM on plant biochemical variables, partly due to the low number or even
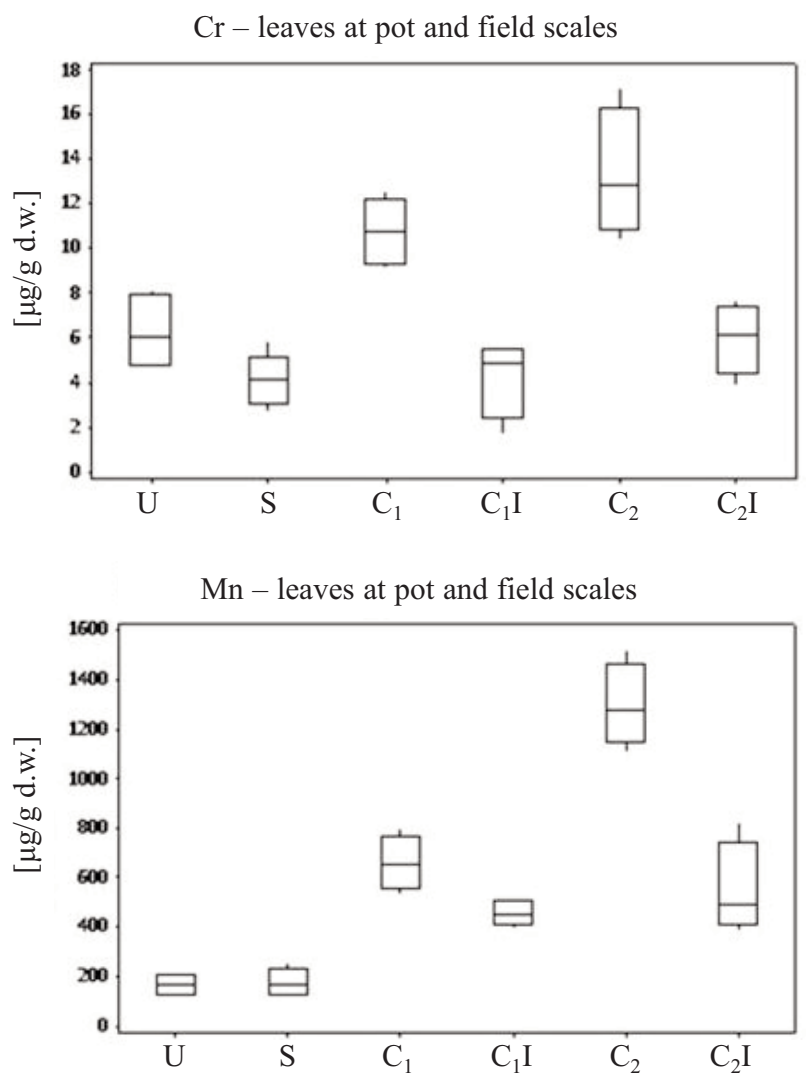

Fig. 1. Variation of metals, metalloids in leaves of sunflower. $\mathrm{U}$ - uncontaminated soil, $\mathrm{C}_{1}$ - contaminated soil $1, \mathrm{C}_{1} \mathrm{I}$ - contaminated inoculated soil $1, \mathrm{C}_{2}$ - contaminated soil 2 , $\mathrm{C}_{2} \mathrm{I}-$ contaminated inoculated soil $2, \mathrm{~S}-$ field soil. 
the absence of soil microorganisms in the case of heavily polluted soils. More attention should be focused on plant responses in combination with those of soil microorganisms.

\section{Acknowledgements}

Field and laboratory activities were performed by means of the PN2 50/2012 ASPABIR partnership project funded by the Executive Agency for Higher Education, Research, Development and Innovation Funding, Romania (UEFISCDI), and data processing and interpretation were done within the PN2 98/2014 TIMMAR partnership project funded by the same Romanian Executive Agency. We thank Valeria Badea for proofreading the English version of our manuscript, Roxana Donciu for help with the lab work, and the anonymous reviewers for their constructive criticism and helpful observations that greatly contributed to improving the final version of this paper.

\section{References}

1. ANN C., KAREN S., JOS R., KELLY O., ELS K., TONY R., NELE H., NATHALIE V. The cellular redox state as a modulator in cadmium and copper responses in Arabidopsis thaliana seedlings. J. Plant. Physiol. 168, 309, 2011.

2. BENITEZ-ALFONSO Y., JACKSON D., MAULE A Redox regulation of intercellular transport. Protoplasma 248, 131, 2011.

3. RAJBIR K., JASMIT K., JYOTI M., RAKESH K., SAROJ A. Oxidative stress-implications, source and its prevention. Environ. Sci. Pollut. Res. Int. 21, (3), 1599, 2014.

4. GHNAYA A.B., CHARLES G., HOURMANT A., HAMIDA J.B., BRANCHARD M. Physiological behavior of four rapeseed cultivar (Brassica napus L.) submitted to metal stress. C R Biol. 332, 363, 2009.

5. BABU N.G., SARMA P.A., ATTITALLA I.H., MURTHY S.D.S. Effect of selected heavy metal ions on the photosynthetic electron transport and energy transfer in the thylakoid membrane of the cyanobacterium, Spirulina platensis. Acad. J. Plant Sci. 3, 46, 2010.

6. SYTAR O., KUMAR A., LATOWSKI D., KUCZYNSKA P., STRZALKA K. PRASAD M.N.V. Heavy metal-induced oxidative damage, defense reactions, and detoxification mechanisms in plants. Acta Physiol. Plant 35, 985, 2013.

7. CLEMENS S. Toxic metal accumulation, responses to exposure and mechanisms of tolerance in plants. Biochimie 88, 1707, 2006.

8. AZCÓN R., DEL CARMEN PERÁlVAREZ M., ROLDÁN A., BAREA J.M. Arbuscular mycorrhizal fungi, Bacillus cereus, and Candida parapsilosis from a multicontaminated soil alleviate metal toxicity in plants. Microb. Ecol. 59, 668, 2010.

9. KABATA-PENDIAS A. Trace Elements in Soils and Plants, forth (Ed.), CRC Press, Boca Raton, Florida, 2011.

10. GADD G.M. Geomycology: biogeochemical transformations of rocks, minerals, metals and radionuclides by fungi, bioweathering and bioremediation. Mycol. Res. 111, (1), 3, 2007.
11. WENZEL W. Rhizosphere processes and management in plant-assisted bioremediation (phytoremediation) of soils. Plant Soil 321, 385, 2008.

12. NEAGOE A., MERTEN D., IORDACHE V., BÜCHEL G. The effect of bioremediation methods involving different degrees of soil disturbance on the export of metals by leaching and by plant uptake. Chemie der Erde 69, 57, 2009.

13. NEAGOE A., IORDACHE V., BERGMANN H., KOTHE E. Pattern of variations of effects of arbuscular mycorrhizal fungi on plants grown in contaminated soil. J. Plant Nutr. Soil Sc. 176, 273, 2013.

14. NEAGOE A., STANCU P., NICOARĂ A., ONETE M., BODESCU F., GHEORGHE R., IORDACHE V. Effects of arbuscular mycorrhizal fungi on Agrostis capillaris grown on amended mine tailing substrate at pot, lysimeter and field plot scales. Environ. Sci. Pollut. Res. 21, (11), 6859, 2013.

15. TURNAU K., RYSZA P., WOJTCZAK G. Metal tolerant mycorrhizal plants: a review from the perspective on industrial waste in temperate region. Arbuscular Mycorrhizal: Physiology and Function, 4, 257, 2010.

16. TURNAU K., GAWROŃSKI S., RYSZKA P., ZOOK D. Mycorrhizal-Based Phytostabilization of Zn-Pb Tailings: Lessons from the Trzebionka Mining Works (Southern Poland). In: Kothe E., Varma A. (eds.) Bio-Geo Interactions in Metal-Contaminated Soils. Soil Biology 31. Springer, Berlin, pp. 327-348, 2012.

17. TURNAU K., PRZYBYLOWICZ W.J., RYSZKA P., ORLOWSKA E., ANIELSKA T., ANIELSKA T., MESIASZ-PRZYBYLOWICZ J. Mycorrhizal fungi modify element distribution in gametophytes and sporophytes of a fern Pellaea viridis from metaliferous soils. Chemosphere 92, 1267, 2013.

18. ARZANESH M., ALIKHANI H., KHAVAZI K., RAHIMIAN H., MIRANSARI M. Wheat (Triticum aestivum L.) growth enhancement by Azospirillum sp. under drought stress. World J. Microbiol. and Biotechnol. 27, 197, 2011.

19. DAZY M., BÉRAUD E., COTELLE S., GRÉVILLIOT F., FÉRARD J.F., MASFARAUD J.F Changes in plant communities along soil pollution gradients: Responses of leaf antioxidant enzyme activities and phytochelatin contents. Chemosphere 77, 376, 2009.

20. AL SAYEGH PETKOVŠEK S. Forest biomonitoring of the largest Slovene thermal power plant with respect to reduction of air pollution. Environ. Monit. Assess. 185, 1809, 2013.

21. FAO-UNESCO. Soil Map of the World, 9 volumes. UNESCO, Paris, France, 1974.

22. PĂUN A., NEAGOE A., BACIU I. The effects of arbuscular mycorrhizal fungi on the transfer of heavy metals and oxidative stress related parameters in sunflower exposed to multielement pollution. Revista de Chimie 63, (2), 146, 2012.

23. KIRKMAN J.H., BASKER A., SURAPANENI A., MACGREGOR A.N. Potassium in the soils of New Zealand-a review. New Zeal. J. Agr. Res., 37, 207, 1994.

24. FOTH H.D., ELLIS B.G. Soil Fertility, $2^{\text {nd }}$ ed.; CRC Press, Boca Raton, Florida, pp. 290, 1997.

25. KABATA-PENDIAS A., PENDIAS H. Trace elements in soils and plants, third (Ed.), CRC Press, Boca Raton, Florida, 2001.

26. INRA. Reference Pedology, French Association of Soil Study, 332, 1995.

27. GRIFFIN G., JOKELA W., ROSS D., PETTINELLI D., MORRIS T., WILF A. Recommended Soil Nitrate Tests. In: Northeastern Regional Publication (Ed.). Recommended Soil Testing Procedures for the Northeastern United States. Cooperative Bulletin No. 493, 27, 2009. 
28. HOWARD A.E. Agronomic thresholds for soil phosphorus in Alberta: A review. In: Alberta Soil Phosphorus Limits Project. Volume 5: Background information and reviews. Alberta Agriculture, Food and Rural Development, Lethbridge, Alberta, Canada. Publishing: Irrigation Branch Alberta Agriculture, Food and Rural Development Lethbridge, Alberta, Canada, pp. 42, 2006.

29. NEAGOE A., EBENA G., CARLSSON E. The effect of soil amendments on plant performance in an area affected by acid mine drainage. Chem. Erde-Geochem. 65, 115, 2005.

30. HOFFMANN G. Book of Methods, Volume 1, The analysis of soils, VDLUFA Publishing House, Darmstadt, 1991.

31. PĂUN A., NEAGOE A., BACIU I. The role of fungi on alleviating the stress induced by heavy metals uptake in rye plants (Secale cereale L.) cultivated in soil from a Romanian industrial area. Revue Roumaine de Chimie 57, (2), 141, 2012

32. VON ALTEN H., BLAL B., DODD J.C., FELDMANN F., VOSATKA M. Quality control of arbuscular mycorrhizal fungi inoculum in Europe. Mycorrhyza Technology in Agriculture: from Genes to Bioproducts, edited by Gianinazzi S., Schüepp H., Barea J.M., Haselwandter K., Birkhäuser Verlag, Basel-Boston-Berlin, pp. 281-296, 2002.

33. SCHMITZ O., DANNEBERG G., HUNDESHAGEN B., KLINGER A., BOTHE H. Quantification of vesiculararbuscular mycorrhiza by biochemical parameters. J. Plant Physiol. 139, 106, 1991.

34. TROUVELOT A., KOUGH J.L., GIANINAZZI-PEARSON V. Measurement of VA mycorrhizal rate of a root system. Estimation methods research with functional significance. In: V. GIANINAZZI-PEARSON, GIANINAZZ S. (Eds. Phisiological and genetical aspects of mycorrhizae, INRA Press, Paris, pp. 217-221, 1986.

35. LOWRY O.H., ROSEBROUGH N.J., FARR A.L., RANDALL R.J. Protein measurement with the Folin phenol reagent. J. Biol. Chem. 193, 265, 1951.

36. MCCORD J.M., FRIDOVICH I. Superoxide dismutase: an enzymatic function for erythrocuprein. J. Biol. Chem. 244, 6049, 1969.

37. LAGRIMINI L.M. Wound - induced deposition of polyphenols in transgenic plants overexpressing peroxidase. Plant Physiol. 96, 577, 1991.

38. HODGES M.D., DELONG J.M., FORNEY C.F., PRAUGE R.K. Improving the thiobarbituric acid-reactive substances assay for estimating lipid peroxidation in plant tissues containing anthocyannand other interfering componds. Planta, 207, 607, 1999.

39. SCHOPFER P. Experimental plant physiology Introduction to the application. Volume 2, Springer, Berlin, 1989.

40. GIOVANNETTI M., SCHUBERT A., CRAVERO M.C., SALUTINI L. Spore production by the vesicular-arbuscular mycorrhizal fungus Glomus monosporum as related to host species, root colonization and plant growth enhancement. Biol. Fert. Soils, 6, (2), 120, 1988.

41. ZANGARO W., ROSTIROLA L.V., DE SOUZA P.B., DE ALMEIDA ALVES R., AZEVEDO MARQUES LESCANO L.E., RONDINA A.B., NOGUEIRA M.A., CARRENHO R. Root colonization and spore abundance of arbuscular mycorrhizal fungi in distinct successional stages from an Atlantic rainforest biome in southern Brazil. Mycorrhiza, 10, 2012
42. MARSCHNER H. Mineral Nutrition of Higher Plants, second (Ed.), Academic Press, London, pp. 889, 1995.

43. SMITHS E., READ D.J. Mycorrhizal symbiosis, $3^{\text {nd }}$ ed., Academic Press Hardbound, pp. 800, 2008.

44. DOUBKOVÁ P., VLASÁKOVÁ E., SUDOVÁ R. Arbuscular mycorrhizal symbiosis alleviates drought stress imposed on Knautia arvensis plants in serpentine soil. Plant Soil 370, 149, 2013

45. ZHAO F.J., MA J.F., MEHARG A.A., MCGRATH S.P. Arsenic uptake and metabolism in plants. New Phytol. 181, 777, 2008.

46. SEDIGHEH H.G., MORTAZAVIAN M., NOROUZIAN D., ATYABI M., AKBARZADEH A., HASANPOOR K., GHORBANI M. Oxidative stress and leaf senescence, BMC Research Notes 4, 477, 2011. http://www.biomedcentral.com/1756-0500/4/477.

47. CHRIST B., HÖRTENSTEINER S. Mechanism and significance of chlorophyll breakdown. J. Plant Growth Regul. 33, 4, 2014.

48. ABDEL LATEF A.A.H. Influence of arbuscular mycorrhizal fungi and copper on growth, accumulation of osmolyte, mineral nutrition and antioxidant enzyme activity of pepper (Capsicum annuum L.). Mycorrhiza, 21, (6), 495, 2011.

49. CONTRERAS L., MELLA D., MOENNE A., CORREA J.A. Differential responses to copper-induced oxidative stress in the marine macroalgae Lessonia nigrescens and Scytosiphon lomentaria (Phaeophyceae). Aquatic Toxicology 94, (2), 94, 2009.

50. JOUILI H., BOUAZIZI H., EL FERJANI E. Plant peroxidases: biomarkers of metallic stress. Acta Physiol. Plant 33, 2075, 2011

51. ARUNAKUMARA K., CHARANA WALPOLA B., YOON M.H. Alleviation of phyto-toxicity of copper on agricultural plants. J. Korean Soc. Appl. Biol. Chem. 56, 505, 2013.

52. HAYAT S., KHALIQUE G., IRFAN M., WANI A.S., TRIPATHI B.N., AHMAD A. Physiological changes induced by chromium stress in plants: an overview. Protoplasma 249, 599, 2012.

53. GONZÁLEZ-GUERRERO M., OGER E., BENABDELLAH K., AZCÓN-AGUILAR C., LANFRANCO L., FERROL N. Characterization of a CuZn superoxide dismutase gene in the arbuscular mycorrhizal fungus Glomus intraradices. Curr. Genet. 56, 265, 2010.

54. TURNAU K., ANIELSKAT., RYSZKAP., GAWROŃSKI S., OSTACHOWICZ B. Establishment of arbuscular mycorrhizal plants originating from xerothermic grasslands on heavy metal rich industrial wastes - new solution for waste revegetation. Plant Soil 305, 267, 2008.

55. ULTRA V.U., TANAKA S., SAKURAI K., IWASAKI K. Effects of arbuscular mycorrhiza and phosphorus application on arsenic toxicity in sunflower (Helianthus annuus L.) and on the transformation of arsenic in the rhizosphere. Plant Soil 290, 29, 2007

56. ULTRA V.U., TANAKA S., SAKURAI K., IWASAKI K. Arbuscular mycorrhizal fungus (Glomus aggregatum) influences biotransformation of arsenic in the rhizosphere of sunflower (Helianthus annuus L.). Soil Science and Plant Nutrition 53, 499, 2007. 
